\title{
Corrosion Resistance of Low Temperature Plasma Nitrided X12CrMoWVNbN10-1-1 Mar- tensitic Stainless Steel
}

David Kusmič, Petr Faltejsek

University of Defence, Department of Mechanical Engineering, Kounicova 65, 60200 Brno-střed, Czech Republic, EU, david.kusmic@unob.cz, petr.faltejsek@email.cz

This paper deals with affecting of corrosion resistance of X12CrMoWVNbN10-1-1 martensitic stainless steel after plasma nitriding. This steel was subjected to plasma nitriding at lower temperature of $400{ }^{\circ} \mathrm{C}$ for $15 \mathrm{~h}$ in the reverse nitriding atmosphere $1 \mathrm{H}_{2}: 3 \mathrm{~N}_{2}(1 / \mathrm{h})$, tested and then compared to untreated one. The microstructure and microhardness of the untreated and nitrided stainless steel were evaluated. The anodic potentiodynamic polarization tests in neutral $2.5 \% \mathrm{NaCl}$ deaerated solution were executed and the corrosion properties of the untreated and plasma nitrided steel samples were evaluated. The results showed a nitride layer, consisting of nitrogen rich diffusion layer but without compound layer on the surface of the plasma nitrided X12CrMoWVNbN10-1-1 stainless steel. The surface hardness of the martensitic stainless steel after plasma nitriding was increased significantly. The corrosion resistance of the $\mathrm{X} 12 \mathrm{CrMoWVNbN10-1-1}$ stainless steel was increased only partially. The pitting was evaluated, and the pitting coefficient was calculated. The plasma nitrided steel showed higher (more positive) corrosion potentials, lower current densities and decreased corrosion rates and pitting during electrochemical corrosion tests compared to not nitrided steel.

Keywords: plasma nitriding, stainless steel, corrosion, pitting, microhardness

\section{Introduction}

One of the basic processes of chemical-heat treatment is the plasma nitriding process, which is used to improve the mechanical properties of structural steels. These includes, for example, surface hardness, fatigue strength $[1,2]$ and tribological properties [3-6]. On the other hand, notch toughness is reduced by plasma nitriding process [7]. Plasma nitriding of structural steels is typically carried out in the range of $450 \div 550{ }^{\circ} \mathrm{C}[1,2]$. Increase of corrosion resistance may occur under certain conditions in the case of structural steels after plasma nitriding [8].

In the case of plasma-nitrided stainless steels, the mechanical properties improvement is similar to the nitrided structural steels. The exception is the corrosion resistance. For stainless steels, corrosion resistance is directly dependent on plasma nitridation parameters. Key parameters includes duration of process, composition of the nitriding atmosphere and especially the temperature at which plasma nitriding takes place. The authors state, that the corrosion resistance of stainless steels can be impaired if the process of plasma nitriding is carried out at temperatures $450{ }^{\circ} \mathrm{C}$ [8], $460{ }^{\circ} \mathrm{C}$ for AISI 304 stainless steel [10], $475{ }^{\circ} \mathrm{C}$ [11] and $480{ }^{\circ} \mathrm{C}$ [12].

It is stated that above this threshold temperature the precipitation of iron and chromium nitrides $(\mathrm{CrN})$ on the grain boundaries in case layer occurs [12]. At temperature of $500{ }^{\circ} \mathrm{C}$ the nitride layer consists of $\mathrm{CrN}, \mathrm{Fe}_{3} \mathrm{~N}$ and $\mathrm{Fe}_{4} \mathrm{~N}$ phases for AISI 304 steel and the pitting corrosion was observed. In the case of plasma nitrided AISI 304 stainless steel at $450{ }^{\circ} \mathrm{C}$ no pitting was observed [10].

\section{Experiments and Results}

For this paper the Martensitic Stainless steel X12CrMoWVNbN10-1-1 (EN 10204/3.1) was chosen. Chemical composition has been verified using the spectrometer Tasman Q4 and compared to inspection certificate, summarized in Table 1. Material for specimens was in form of blocks of steel prepared. They were hardened $\left(1080^{\circ} \mathrm{C} / 2 \mathrm{~h} /\right.$ oil $)$, tempered $\left(740^{\circ} \mathrm{C} / 4 \mathrm{~h} /\right.$ air $)$, and stress-free annealed $\left(700^{\circ} \mathrm{C} / 3 \mathrm{~h} /\right.$ air $)$. Final hardness was $241 \div 255$ HBW5 and J factor 91.2. Blocks of steel were cut into samples. Standard samples of diameter $13 \mathrm{~mm}$ and approximately of $10 \mathrm{~mm}$ thickness were prepared. Surface of samples was grinded to final roughness $\mathrm{Ra}=$ $0.4 \mu \mathrm{m}$ and then degreased in ethanol prior plasma nitriding process and before every measurement.

Tab. 1 Chemical composition of X12CrMoWVNbN10-1-1 steel in wt.\%

\begin{tabular}{l|cccccccccccc} 
& $\mathrm{C}$ & $\mathrm{Si}$ & $\mathrm{Mn}$ & $\mathrm{Cr}$ & $\mathrm{Ni}$ & $\mathrm{Mo}$ & $\mathrm{V}$ & $\mathrm{Cu}$ & $\mathrm{W}$ & $\mathrm{N} 2$ & $\mathrm{P}$ & $\mathrm{S}$ \\
\hline Certificate & 0.1 & 0.11 & 0.46 & 10.6 & 0.83 & 1.03 & 0.2 & 0.08 & 0.95 & 0.043 & 0.009 & 0.007 \\
Tasman Q4 & 0.1 & 0.03 & 0.47 & 10.4 & 1.02 & 1.08 & 0.19 & 0.08 & 1.12 & 0.1 & 0.010 & 0.009 \\
\hline
\end{tabular}

Prepared samples were subjected to plasma nitriding process with following operating parameters: Nitriding atmosphere $1 \mathrm{H}_{2}: 3 \mathrm{~N}_{2}(\mathrm{l} / \mathrm{h})$ gas ratio, process duration 15 hours, at $400{ }^{\circ} \mathrm{C}$ in the RUBIG PN 60/60 device.
Samples were studied by optical microscopy. Existence of martensitic structure (Fig. 1a) was observed. Thanks to etching by $5 \%$ Nital the diffusion layer was visible. 


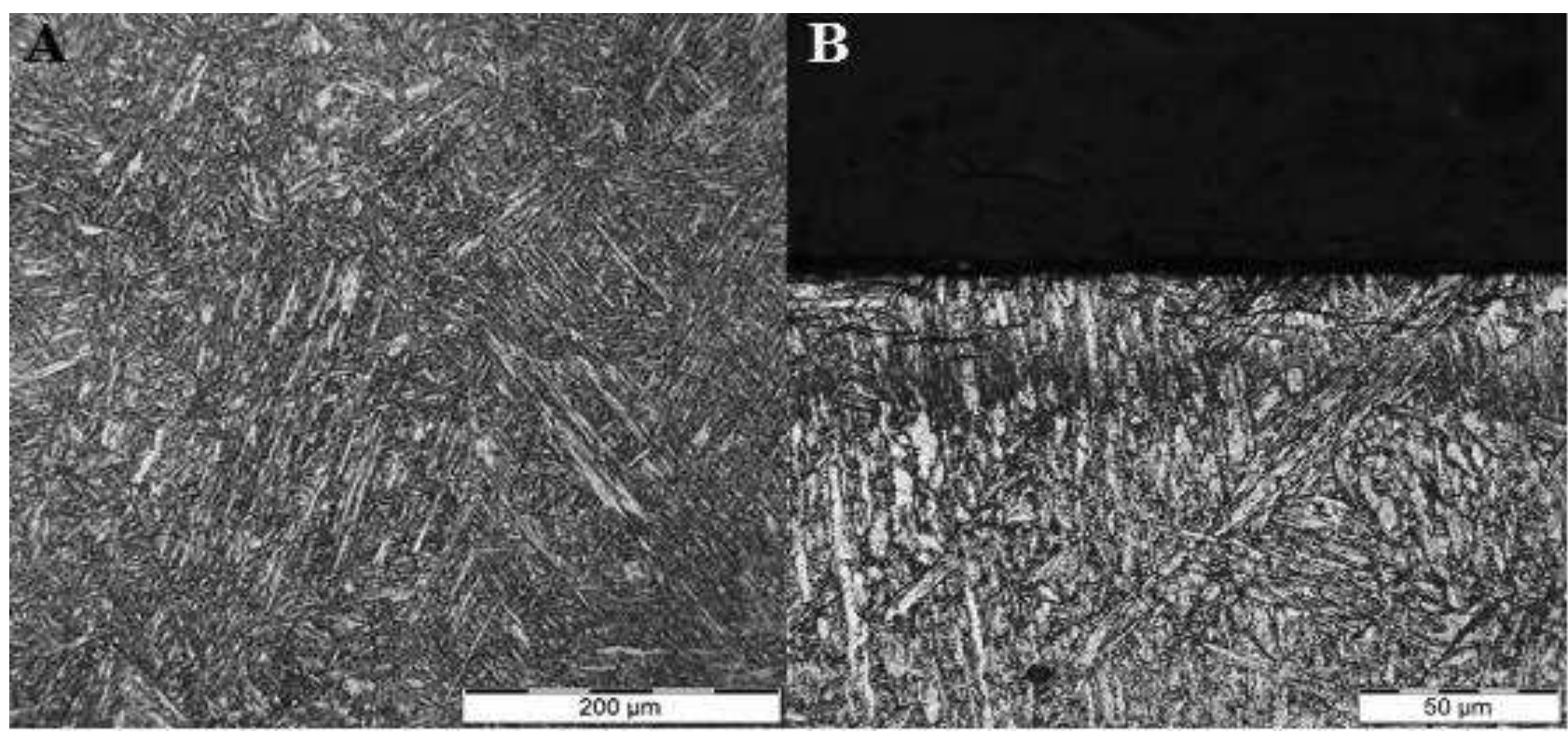

Fig. 1 A) Microstructure of untreated steel, B) plasma nitrided steel with absence of compound layer and created diffusion layer (5\% Nital)

The case layer depth reached $0.0754 \mathrm{~mm}$, evaluated by microhardness measuring using LECO LM247 AT microhardness tester (DIN 50190), see Fig. 2.

Surface hardness was measured after plasma nitriding and increased from original value of bare material $295 \pm$ $11 \mathrm{HV}$ to $1124 \pm 65 \mathrm{HV}$.

Thank to lower nitriding temperature, any compound layer was formed.

Surfaces of plasma nitrided samples and untreated samples were additionally documented by the optical microscopy (OLYMPUS DSX 100) after anodic potentiodynamic electrochemical tests (Figure 3.)
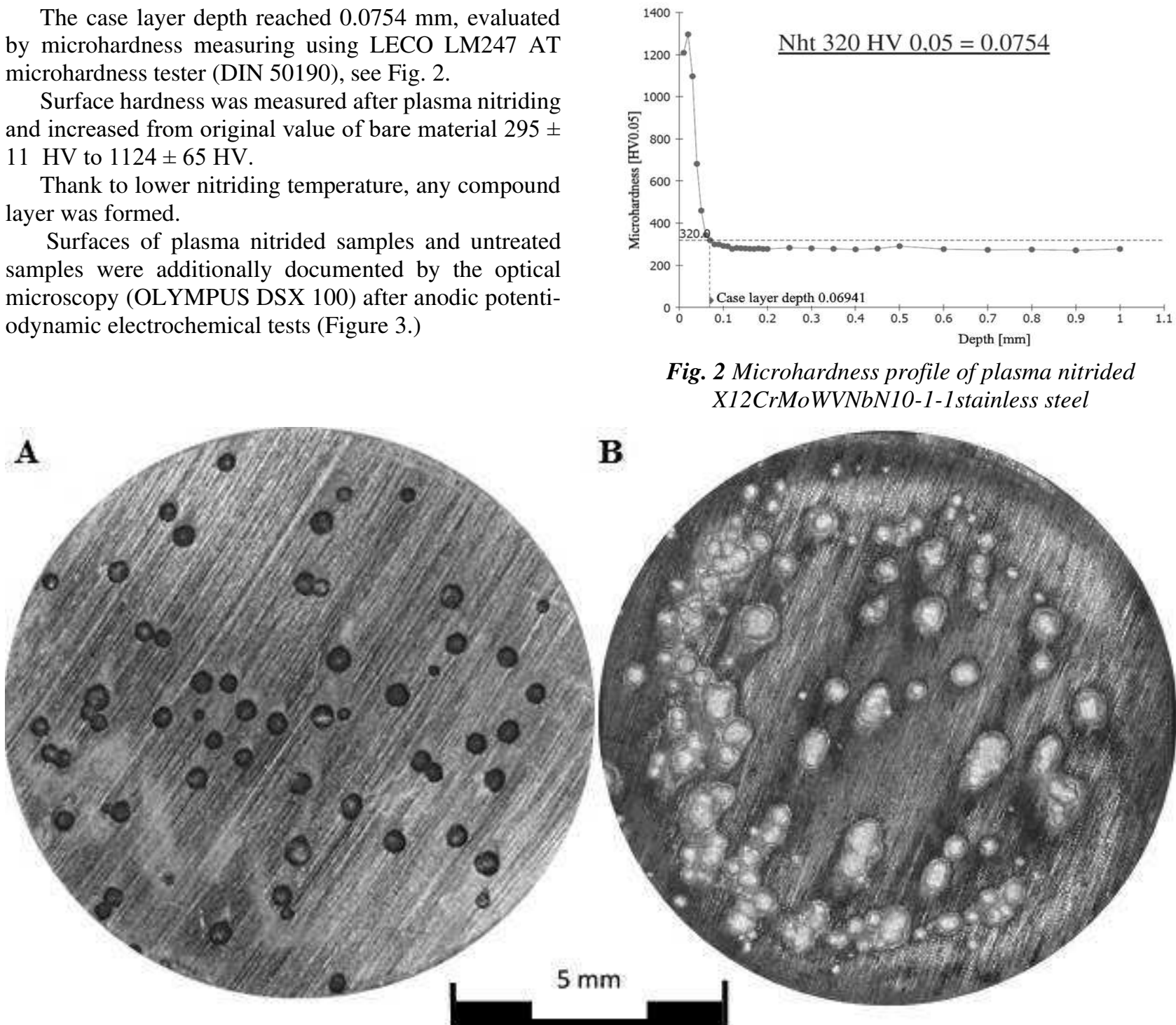

Fig. 2 Microhardness profile of plasma nitrided X12CrMoWVNbN10-1-1stainless steel

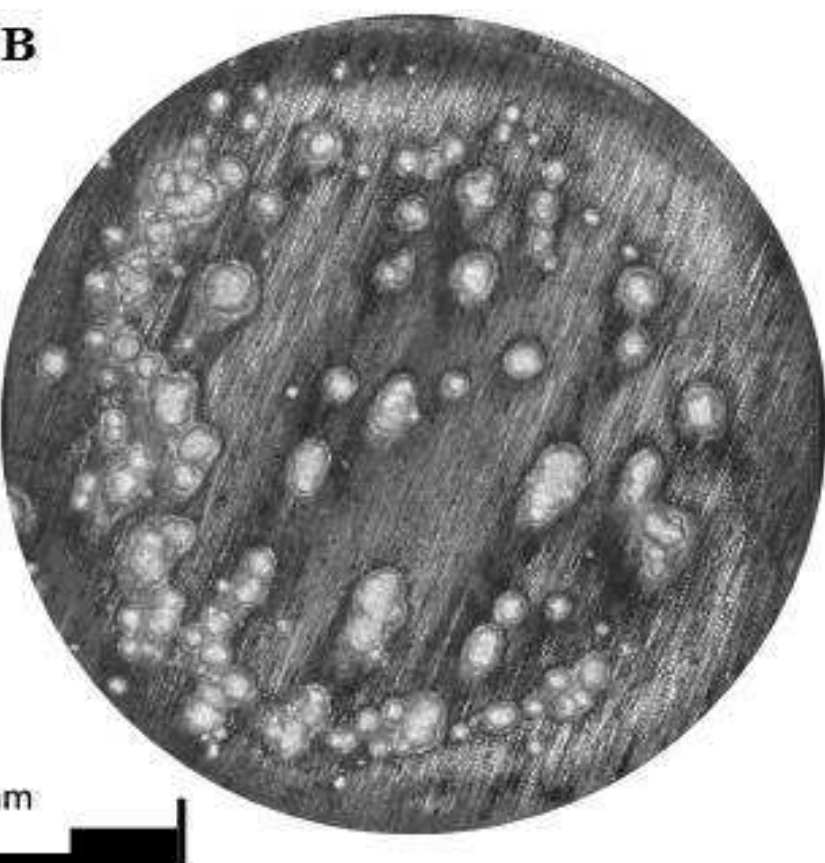

Fig. 2 Pitting on the X12CrMoWVNbN10-1-1 steel after anodic potentiodynamic tests $(A)$ untreated, $(B)$ nitrided 
After anodic potentiodynamic polarization tests pitting was evaluated using the laser confocal microscopy (OLYMPUS OLS 3000) and the pitting factor (PF) was calculated according to ISO 11463 standard, as ratio of deepest pit to the average of 10 measured pits.

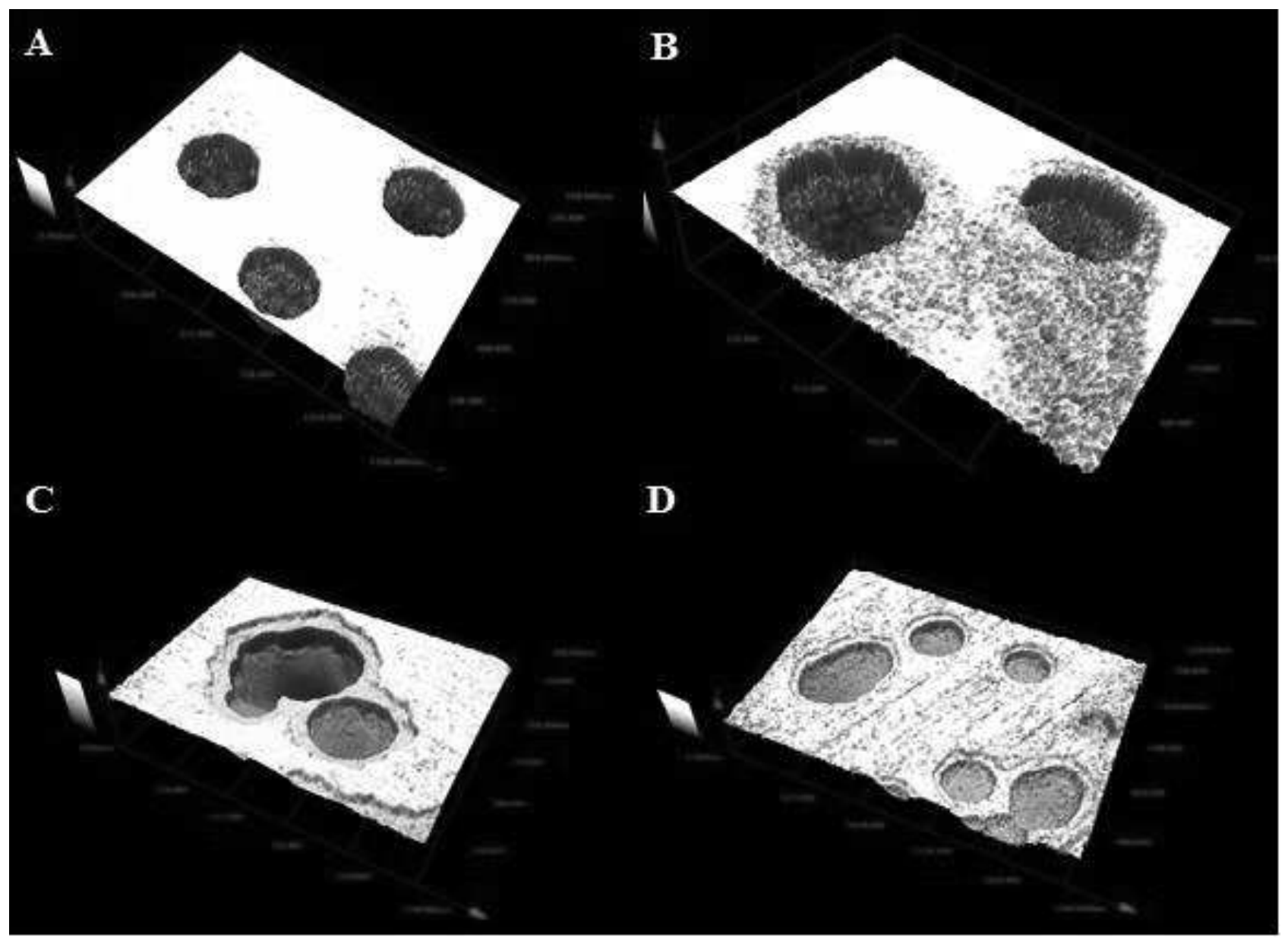

Fig. 3 Pitting - Laser confocal microscopy LEXT OLS 3000. (A, B) untreated steel, (C, D) plasma nitrided steel.

For plasma nitrided steel sample the calculated value of PF reached 1.22 and for untreated sample 1.28. Additionally, width and depth of pits was measured. For plasma nitrided sample average width of pits was $815.25 \mu \mathrm{m}$ and for untreated sample $340.16 \mu \mathrm{m}$ (Figures 3 and 4).

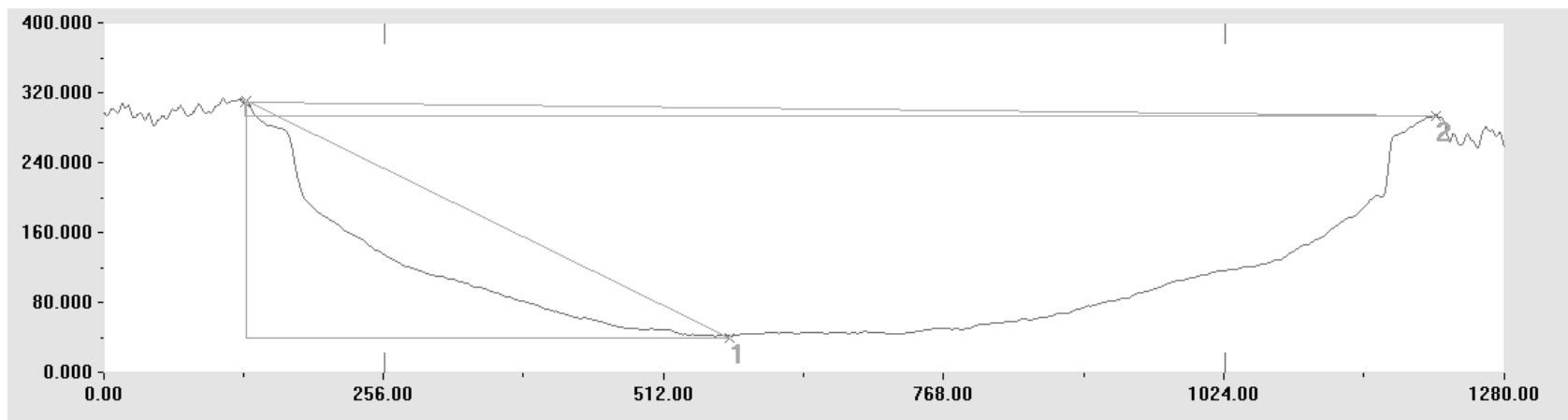

Fig. 4 The 2D measuring of pitting geometry (LEXT OLS 3000), plasma nitrided steel after anodic potentiodynamic polarization tests

On the plasma nitrided martensitic X12CrMoWVNbN10-1-1 stainless steel the anodic potentiodynamic polarization tests were carried out. The Biologic SP 150 potentiostat and software EC-Lab V11.10. were used. The Cyclic Potentiodynamic Polarization method (ASTM-61) was chosen. with following parameters: sweep speed $\mathrm{dE} / \mathrm{dt}=0.166 \mathrm{mV} / \mathrm{s}, \mathrm{Ei}=-0.25 \mathrm{~V}, \mathrm{EL}=2 \mathrm{~V}$, $\mathrm{Ip}=25 \mathrm{~mA}$, E range $(-2 \mathrm{~V} ; 2 \mathrm{~V})$ at ambient temperature. Measured surface of steel samples was $0.865 \mathrm{~cm}^{2}$. Samples were exposed to neutral deaerated $2.5 \% \mathrm{NaCl}$ solution. 


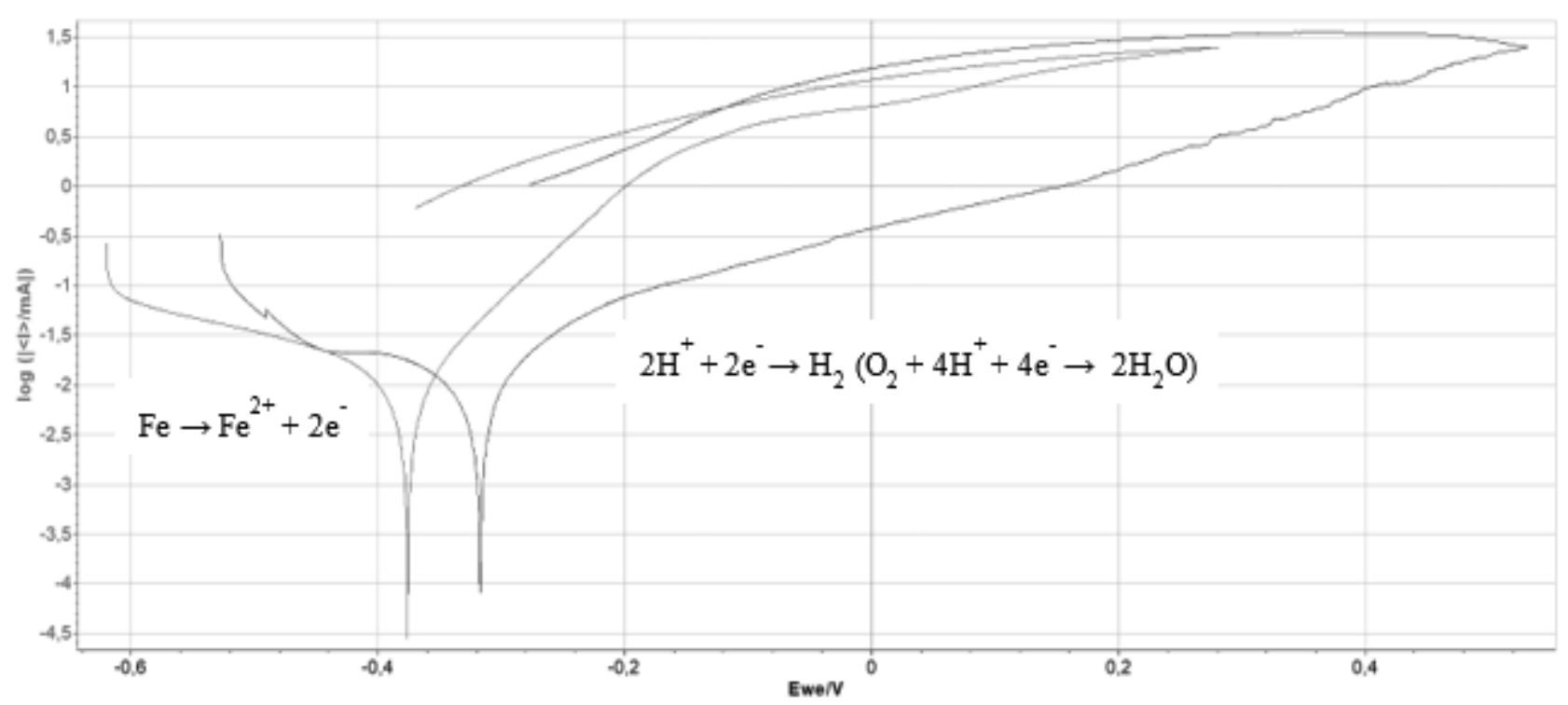

Fig. 5 Potentiodynamic curves of X12CrMoWVNbN1O-1-1 steel in deaerated 2.5\% NaCl solution. (red lined) Plasma nitrided at $400^{\circ} \mathrm{C}$, (blue lined) untreated steel.

Anodic potentiodynamic measurement involves polarizing the working electrode (sample) from its equilibrium potential Eoc (OCP - open circuit potential), by steadily shifting DC potential difference between the working electrode and the counter electrode (Supersaturated Calomel Electrode) by the potentiostat, while recording the current response (see Figure 5.). The Tafels constants and calculations represents average values of three measurements are summarized in Table 2.

Tab. 2 Results of potentiodynamic electrochemical tests on X12CrMoWVNbN10-1-1

\begin{tabular}{c|cccccc} 
& $\mathrm{E}_{\mathrm{oc}}(\mathrm{mV})$ & $\mathrm{E}_{\mathrm{corr}}(\mathrm{mV})$ & $\mathrm{I}_{\text {corr }}(\mathrm{mA})$ & $\beta \mathrm{c}(\mathrm{mV})$ & $\beta \mathrm{a}(\mathrm{mV})$ & $\mathrm{v}_{\text {corr }}\left(\mathrm{mm} / \mathrm{a}^{-1}\right)$ \\
\hline Untreated & -645 & -384.900 & 14.820 & 298.625 & 125.575 & 0.198 \\
Plasma nitrided & -316 & -425.389 & 16.049 & 1156.750 & 285.000 & 0.189 \\
\hline
\end{tabular}

\section{Conclusion}

This paper describes corrosion resistance of low temperature plasma nitrided X12CrMoWVNbN10-1-1 martensitic stainless steel evaluated using the anodic potentiodynamic tests in deaerated $2.5 \% \mathrm{NaCl}$ solution compared to untreated sample.

The low temperature plasma nitriding increased surface hardness from $295 \pm 11 \mathrm{HV}$ to $1124 \pm 65 \mathrm{HV}$ and created case layer of $0.0754 \mathrm{~mm}$.

The corrosion resistance of untreated martensitic stainless steel was similar to corrosion resistance of plasma nitrided one. Corrosion rate was slightly decreased.

According to calculated pitting factor (PF) can be concluded, the pitting for plasma nitrided steel was reduced $(\mathrm{PF}=1,22)$ compared to untreated steel $(\mathrm{PF}=$ $1.28)$, but the average width of pits for nitrided steel was more than doubled.

Summary, the low temperature plasma nitriding in reverse nitriding gas ratio atmosphere of X12CrMoWVNbN10-1-1 steel slightly improved the corrosion resistance and greatly increased the surface hardness.

\section{Acknowledgements}

The present research work was supported by the project The Development of Technologies, Design of Firearms,
Ammunition, Instrumentation, Engineering of Materials and Military Infrastructure "VÝZBROJ (DZRO K201)" and "Surface technology in applications special techniques SV18-216".

\section{References}

[1] STUDENY, Z., DOBROCKY, D., POKORNY, Z. (2017). Importance of diffusion proces on the fatigue life of steel. In: Manufacturing Technology, Vol. 17, No. 1, pp. 94-99. Institute of Technology and Production Management University of J.E. Purkyne.

[2] KRBATA, M., MAJERIK, J., BARENYI, I., MIKUSOVA, I., KUSMIC, D. (2019). Mechanical and Tribological Features of the 90MnCrV8 Steel after Plasma Nitriding. In: Manufacturing Technology, Vol. 19, No. 2, pp. 238-242. Institute of Technology and Production Management University of J.E. Purkyne.

[3] ESPITIA, L. A., DONG, H., LI, X.-Y., PINEDO, C.E., TSCHIPTSCHIN, A. P. (2017). Scratch test of active screen low temperature plasma nitrided AISI 410 martensitic stainless steel. In: Wear, Vol. 376-377, Part A, pp 30-36, Elsevier B.V. 
[4] ROVANI, Ane C., BREGANON, R., DE SOUZA, G. S., BRUNATTO, S. F.,PINTAÚDE, G. (2017). Scratch resistance of low-temperature plasma nitrided and carburized martensitic stainless steel. In: Wear, Vol. 376-377, Part A, pp. 7076, Elsevier B.V.

[5] DOBROCKY, D., POKORNY, Z., STUDENY, Z., DOSTAL, P. (2019). Change of Selected Parameters of Steel Surface after Plasma Nitriding. In: Manufacturing Technology, Vol. 19, No. 2, 2019, pp. 204-208. Institute of Technology and Production Management University of J.E. Purkyne.

[6] KADLEC, J., JOSKA, Z., POKORNY, Z. (2011). Plasma treatment of stainless steel surface. In: ECS Transactions, Vol. 32, Issue 1, pp. 69-72. Electrochemical Society, Inc.

[7] DOBROCKY, D., STUDENY, Z., POKORNY, Z., POSPICHAL, M. SMIDA, O. (2016). Effect of plasma nitriding on the notch toughness of spring steel. In: METAL 2016, pp. 1037-1044. Tanger Ltd, Ostrava.

[8] KUSMIČ, D., ČECH, O., FALTEJSEK, P. (2018). Duplex treatment of plasma nitriding and manganese phosphating of $42 \mathrm{CrMo} 4$ steel for corrosion resistance increasing. In: METAL 2018. pp. 1077-1084. Tanger Ltd, Ostrava.

[9] YANG, W.J., ZHANG, M., ZHAO, Y.H. et al. (2016). Enhancement of mechanical property and corrosion resistance of $316 \mathrm{~L}$ stainless steels by low temperature arc plasma nitriding. In: Surface and Coatings Technology, Vol. 298, No. C, pp. 64-7., Elsevier Science.

[10] LIANG, W. (2003). Surface modification of AISI 304 austenitic stainless steel by plasma nitriding. In: Applied Surface Science, Vol. 211, Issues 1-4, pp. 308-314. Elsevier B.V.

[11] MENTHE, E., RIE, K.-T. (1999). Further investigation of the structure and properties of austenitic stainless steel after plasma nitriding. In: Surface and Coatings Technology, Vol. 116-119, pp. 199204. Elsevier Science.

[12] LI, Y., WANG, Z., WANG, L. (2014). Surface properties of nitrided layer on AISI 316L austenitic stainless steel produced by high temperature plasma nitriding in short time. In: Corrosion Science, Vol. 48, Issue 8, pp. 2036-2049, Elsevier Ltd. 